\title{
Analisis Kebutuhan Kompetensi Lulusan Akuntansi
}

\author{
Anda Dwiharyadi ${ }^{1}$, Novi Asrina ${ }^{2}$, Eka Rosalina ${ }^{3 *}$ \\ ${ }^{1}$ Jurusan Akuntansi, Politeknik Negeri Padang \\ Email: anda.dwiharyadi@gmail.com \\ 2Jurusan Akuntansi, Politeknik Negeri Padang \\ Email:noviasrina15@gmail.com \\ 3Jurusan Akuntansi, Politeknik Negeri Padang \\ Email: ekarosalinapnp5@gmail.com \\ *Corresponding Author
}

\begin{abstract}
In accordance with the demands of the times in today's digital era resulting in the industry looking for skilled human resources in their fields. Job seekers are required to have the skills expected by the industry in order to compete for the expected job positions. For that it is important for job seekers to equip themselves with skills that are the needs of the industry. Skill improvement needs support from educational institutions in creating skilled human resources in accordance with the qualifications required by the industry. This study aims to identify what is needed from an accounting graduate. This research was conducted with descriptive quantitative method, with content analysis approach. By using the incidental sampling technique, 705 industrial job vacancies were published on the online job vacancy website for the period January 2021 to June 2021. This study focuses on accounting work including financial accountants, auditors, and tax accountants. The results showed that the basic technical skills of accounting (Technical Skills) which include basic understanding of accounting, mastery of accounting software and Microsoft office are the skills most needed by the world of work. Meanwhile, the generic skills needed by the industry are communication skills, which are derived skills from interpersonal skills.
\end{abstract}

Keywords: accounting graduate, competence, technical skill, generic skill

\begin{abstract}
ABSTRAK
Sesuai dengan tuntutan zaman di era digital saat ini mengakibatkan industri mencari sumber daya manusia yang terampil di bidangnya. Pencari kerja dituntut untuk memiliki keterampilan yang diharapkan oleh industri agar dapat bersaing untuk mendapatkan posisi pekerjaan yang diharapkan. Untuk itu penting bagi pencari kerja untuk membekali diri dengan keterampilan yang menjadi kebutuhan industri. Peningkatan keterampilan perlu dukungan dari lembaga pendidikan dalam menciptakan sumber daya manusia yang terampil sesuai dengan kualifikasi yang dibutuhkan oleh industri. Penelitian ini bertujuan untuk mengidentifikasi kompetensi apa saja yang dibutuhkan dari seorang lulusan akuntansi. Penelitian ini dilakukan dengan metode kuantitatif deskriptif, dengan pendekatan analisis konten. Dengan menggunakan teknik insdental sampling diperoleh 705 lowongan kerja industri yang terbit pada situs web lowongan kerja online periode Januari 2021 sampai dengan Juni 2021. Penelitian ini fokus pada bidang pekerjaan akuntansi meliputi akuntan keuangan, auditor, dan akuntan pajak. Hasil penelitian menunjukkan bahwa keterampilan teknis dasar akuntansi (Technical Skill) yang meliputi, pemahaman dasar akuntansi, penguasaan software akuntansi dan Microsoft office merupakan keterampilan yang paling dibutuhkan oleh dunia kerja. Sementara itu,
\end{abstract}


untuk keterampilan generik (Generic Skill) yang dibutuhkan industri yaitu kemampuan komunikasi yang merupakan keterampilan turunan dari keterampilan interpersonal.

Kata kunci: lulusan akuntansi, kompetensi, keterampilan teknis, keterampilan generic

\section{Pendahuluan}

Sesuai dengan tuntutan zaman di era digital saat ini mengakibatkan industri mencari sumber daya manusia yang terampil di bidangnya. Pencari kerja dituntut untuk memiliki keterampilan yang diharapkan oleh industri agar dapat bersaing untuk mendapatkan posisi pekerjaan yang diharapkan. Pada Februari 2021, di Indonesia terdapat jumlah pengangguran yang tercatat di Badan Pusat statistik (BPS) mencapai 8,75 Juta orang. Dimana jumlah tersebut mengalami peningkatan sebanyak 26,26\% dibandingkan dengan periode Februari 2020 yaitu sebesar 6,93 Juta Orang. Berdasarkan survei angkatan kerja nasional Tingginya tingkat pengangguran di Indonesia salah satunya disebabkan oleh pandemi COVID-19 terhadap ketenagakerjaan Indonesia. Dalam menghadapi tuntutan zaman, pendidikan di Indonesia dihadapkan dengan tantangan untuk menciptakan lulusan sumber daya manusia yang memiliki keterampilan di bidangnya.

Untuk itu penting bagi pencari kerja untuk membekali diri dengan keterampilan yang menjadi kebutuhan industri. Peningkatan keterampilan perlu dukungan dari lembaga pendidikan dalam menciptakan sumber daya manusia yang terampil sesuai dengan kualifikasi yang dibutuhkan oleh industri. Persaingan yang ketat dalam mencari pekerjaan di era digital saat ini mengakibatkan pencari kerja tidak hanya bersaing dengan sesamanya, tetapi juga harus mampu memenuhi kualifikasi yang dituntut oleh industri. Menurut Kamus Besar Bahasa Indonesia (KBBI) keterampilan merupakan kecakapan untuk menyelesaikan tugas. Keterampilan dapat dicapai secara maksimal jika terdapat dorongan kemauan yang kuat dari diri seseorang untuk belajar secara berkelanjutan, melatih diri untuk menguasai sesuatu keterampilan di bidang tertentu. Dengan demikian, relevansi antara proses belajar dengan kebutuhan dunia industri sangat dibutuhkan dalam meramu kurikulum [5] .

Penelitian yang dilakukan oleh [3] menunjukan bahwa soft skills lebih diutamakan dari pada hardskills dikalangan pengusaha. Penelitian lain seperti yang dilakukan oleh [2] dengan menganalisis salah satu website lowongan kerja online, dimana terdapat 523 iklan lowongan kerja online menunjukan bahwa keterampilan yang paling penting di butuhkan oleh lulusan akuntansi adalah keterampilan interpersonal (Interpersonal Skill) dan keterampilan komunikasi. Maka dari itu penting bagi lulusan sarjana akuntansi harus bisa mengukur kemampuan yang dimiliki dengan keterampilan yang diharapkan industri agar dapat meningkatkan peluang untuk dapat diterima saat melamar pekerjaan ke industri yang dituju. Maka dari itu peran pendidikan diharapkan mampu menciptakan sumber daya manusia yang dapat memenuhi kualifikasi yang dibutuhkan industri baik dari segi keterampilan teknis (Technical Skills) maupun keterampilan generik (Generic Skills). Melihat pentingnya hal tersebut penelitian ini perlu sebagai bahan pertimbangan bagi lembaga pendidik untuk 
melakukan evaluasi dan relevansi keterampilan yang dibutuhkan oleh industri agar sumber daya manusia yang diciptakan siap bekerja dan terampil di bidangnya.

\section{Metode Penelitian}

Penelitian ini merupakan penelitian deskriptif. Pengambilan sampel menggunakan non probability sampling dengan teknik sampling insidental. Teknik sampling insidental adalah teknik pengumpulan sampel berdasarkan kebetulan, yang mana secara tidak sengaja data ditemukan dan dapat digunakan sebagai sampel [11]. Data diperoleh dari beberapa situs lowongan kerja online yaitu loker.id, topkarir.com, karir.com, dan jobstreet.com. Data yang diperoleh dari situs loker.id, topkarir.com, karir.com, dan jobstreet.co.id berupa iklan lowongan kerja di bidang akuntansi yang sesuai dengan kriteria penelitian. Loker online dipantau setiap harinya, lalu diterapkan filter tanggal untuk melihat loker terbaru dari industri yang berbeda, dan filter bagian bidang akuntansi untuk melihat spesifikasi iklan kerja bagian akuntansi.

\section{Hasil dan Pembahasan}

Penelitian ini fokus pada bidang pekerjaan akuntansi meliputi akuntan keuangan, auditor, dan akuntan pajak. Dari website loker online loker.id, topkarir.com, karir.com, dan jobstreet.com periode Januari 2021 sampai dengan Juni 2021 ditemukan bahwa pada bidang keuangan terdapat 334 iklan lowongan kerja, bidang perpajakan 299 iklan lowongan kerja, dan pada bidang audit 72 iklan iklan lowongan kerja. Terlihat bahwa dari tiga bidang tersebut permintaan terbanyak yaitu bidang keuangan. Selanjutnya peneliti mengelompokan berdasarkan kategori jabatan yang dibutuhkan di industri yang menerbitkan iklan secara online. Terdapat 20 kategori bidang pekerjaan akuntansi.

Tabel 1. Pengelompokan Jabatan Bidang Akuntansi

\begin{tabular}{|l|l|l|}
\hline No & \multicolumn{1}{|c|}{ Kategori } & Jumlah \\
\hline 1 & Auditor Eksternal & 4 \\
\hline 2 & Auditor Internal & 68 \\
\hline 3 & Asisten Akuntan & 4 \\
\hline 4 & Asisten Keuangan & 1 \\
\hline 5 & Bookkeeper & 1 \\
\hline 6 & Financial Controller & 19 \\
\hline 7 & Kepala Staf Akuntansi & 21 \\
\hline 8 & Kepala Staf Akuntansi dan Keuangan & 8 \\
\hline 9 & Konsultan Keuangan & 4 \\
\hline 10 & Manager Keuangan & 7 \\
\hline 11 & Staff Account Receivable & 3 \\
\hline 12 & Staff Account Payable & 1 \\
\hline
\end{tabular}




\begin{tabular}{|l|l|l|}
\hline No & \multicolumn{1}{|c|}{ Kategori } & Jumlah \\
\hline 13 & Staf Admin & 8 \\
\hline 14 & Staf Akuntansi & 186 \\
\hline 15 & Staf Keuangan & 71 \\
\hline 16 & Admin Faktur Pajak & 5 \\
\hline 17 & Kepala Staf Pajak & 1 \\
\hline 18 & Konsultan Pajak & 14 \\
\hline 19 & Staf Akuntansi dan Pajak & 249 \\
\hline 20 & Staf Pajak & 30 \\
\hline Total & & 705 \\
\hline
\end{tabular}

Sumber : Data diolah, 2021

Terlihat bahwa permintaan yang paling tinggi terdapat pada staf akuntansi dan pajak yaitu sebanyak 249 lowongan yang dibutuhkan industri, dan staf akuntansi sebanyak 186 lowongan pekerjaaan yang dibutuhkan industri. Setelah dikategorikan, Selanjutnya diterapkan dummy dengan angka 1 (satu) jika persyaratan lowongan kerja pada iklan lowongan kerja akuntansi sesuai dengan indikator atau diberikan angka 0 (nol) jika tidak ditemukan indikator yang diteliti pada persyaratan iklan lowangan kerja. Tahapan ini dilakukan untuk mengetahui keterampilan yang paling dibutuhkan untuk setiap kategori. Setelah semua data dianalisis dan dilakukan pengkodean, data yang di kelompokan dianalisis dan ditampilkan dalam bentuk persentase untuk mengetahui keterampilan profesional yang paling dibutuhkan oleh industri dalam iklan lowongan kerja online untuk setiap katagori bidang pekerjaan akuntansi.

Tabel 2 menunjukan keterampilan profesional yang dibutuhkan oleh lulusan akuntansi di Indonesia berdasarkan sub bidang pekerjaan akuntansi yaitu keuangan, perpajakan, dan audit. Secara keseluruhan keterampilan teknis dasar akuntansi (Technical Skill) paling dibutuhkan oleh lulusan sarjana akuntansi untuk memenuhi kebutuhan yang diharapkan oleh dunia kerja. Untuk itu perlu bagi perguruan tinggi untuk mengembangkan kurikulum yaitu dengan menambahkan porsi lebih besar untuk pembelajaran terkait pemahaman teori dasar akuntansi, peraturan terkait bidang akuntansi, perpajakan, maupun audit. Pada pembelajaran praktikum, perlu bagi perguruan tinggi untuk memanfaatkan berbagai teknologi serta aplikasi yang berpotensi banyak digunakan dalam dunia kerja untuk menunjang pekerjaan bidang akuntansi, keuangan, pajak, dan audit seperti penggunaan Microsoft Office, dan software akuntansi MYOB (Mind Your Own Business), accurate, ATLAS (Audit Tool and Linked Archive System), SAP (System Application And Processing), Software pajak (ESPT, E-Billing, E-Filling, E-Registration yang disediakan oleh Dirjen Jenderal Pajak (DJP), dan aplikasi lainnya yang mendukung kerja dibidang akuntansi.

Namun, pada intinya semua bidang pekerjaan akuntansi membutuhkan pekerja yang memiliki kemampuan yang seimbang antara keterampilan teknis dasar akuntansi 
(Technical Skill) biasanya dikenal dengan keterampilan yang didapatkan dari jalur pendidikan resmi keterampilan ini berupa kemampuan atau keahlian pada bidang spesialisasi tertentu dalam penelitian ini yaitu kemampuan atau keahlian pada bidang spesialis akuntansi dan keterampilan generik (Generic Skill) juga bisa disebut dengan keterampilan umum yang digunakan setiap orang untuk berbagai bidang kehidupan dan kerja, meliputi intellectual skill, personal skill ,dan interpersonal skill, akan tetapi pada lowongan kerja online tidak dijabarkan satu persatu. Artinya hanya beberapa persyaratan saja yang dituliskan secara eksplisit pada iklan lowongan kerja yang dimuat pada situs web lowongan kerja online.

Tabel 2. Keterampilan Pada Sub Bidang Akuntansi yang Dibutuhkan Oleh Lulusan Akuntansi

\begin{tabular}{|c|c|c|c|c|c|}
\hline \multirow{2}{*}{ No } & \multirow{2}{*}{ Bidang } & \multirow{2}{*}{ Technical Skill } & \multicolumn{3}{|c|}{ Generic Skill } \\
\hline & & & Intellectual & Personal & Interpersonal \\
\hline 1 & Keuangan & 334 & 58 & 77 & 83 \\
\hline 2 & Perpajakan & 299 & 50 & 59 & 84 \\
\hline 3 & Audit & $\underline{70}$ & $\underline{19}$ & $\underline{20}$ & $\underline{20}$ \\
\hline \multicolumn{2}{|c|}{ Total } & 703 & 127 & 156 & 187 \\
\hline \multicolumn{2}{|c|}{ Jumlah \% } & $60 \%$ & $11 \%$ & $13 \%$ & $16 \%$ \\
\hline
\end{tabular}

Sumber : Data diolah, 2021

Selanjutnya pada tabel 2 menunjukan peringkat kompetensi yang dibutuhkan berdasarkan persentase tertinggi dalam iklan lowongan kerja akuntansi di Indonesia. Jika dilihat secara keseluruhan dari ketiga bidang akuntansi yang diteliti terlihat juga bahwa kemampuan yang paling dibutuhkan dari seorang lulusan akuntansi adalah keterampilan teknis (Technical skill), yang meliputi pemaham terhadap dasar pengetahuan teknis, dan pemahaman software terkait akuntansi serta penguasaan terhadap microsoft office sebagai kemampuan dasar penggunaan komputer. Sementara, mengembangkan informasi merupakan kompetensi yang paling sedikit disebutkan dalam lowongan pekerjaan. Akan tetapi dalam prakteknya, semua atribut atau indikator pada tabel diatas dibutuhkan dalam proses bekerja di bidang akuntansi. Seorang lulusan akuntansi juga memerlukan keterampilan yang seimbang untuk menunjang kinerjanya pada suatu industri. Tidak hanya keterampilan teknis (Technical Skill), keterampilan generic (Generic Skill) juga sangat dibutuhkan dalam dunia kerja. 
https://akuntansi.pnp.ac.id/jam

Tabel 3. Urutan Persentase Keterampilan yang Dibutuhkan Lulusan Akuntansi Dalam Iklan Lowongan Kerja Online

\begin{tabular}{|c|c|c|c|}
\hline No & Keterampilan & & $\%$ \\
\hline 1 & Technical Skill & Memahami Dasar Pengetahuan Teknis & $15,1 \%$ \\
\hline 2 & Technical Skill & Software terkait akuntansi & $15,1 \%$ \\
\hline 3 & Technical Skill & Ms office & $15,0 \%$ \\
\hline 4 & Interpersonal Skill & Komunikasi & $11,3 \%$ \\
\hline 5 & Interpersonal Skill & Bekerja dalam tim & $6,9 \%$ \\
\hline 6 & Personal Skill & Tanggung Jawab & $5,8 \%$ \\
\hline 7 & Personal Skill & Bekerja di bawah tekanan dan deadline & $5,1 \%$ \\
\hline 8 & Intellectual Skill & Analitis & $4,0 \%$ \\
\hline 9 & Personal Skill & Kepribadian baik & $3,8 \%$ \\
\hline 10 & Intellectual Skill & Memecahkan masalah & $3,1 \%$ \\
\hline 11 & Interpersonal Skill & Bahasa asing & $2,4 \%$ \\
\hline 12 & Interpersonal Skill & Kepemimpinan & $2,2 \%$ \\
\hline 13 & Personal Skill & Adaptasi & $2,1 \%$ \\
\hline 14 & Intellectual Skill & Kritis & $2,1 \%$ \\
\hline 15 & Personal Skill & Multitasking & $1,7 \%$ \\
\hline 16 & Intellectual Skill & Kreatif & $1,7 \%$ \\
\hline 17 & Personal Skill & Manajemen waktu & $1,5 \%$ \\
\hline 18 & Interpersonal Skill & Presentasi & $0,9 \%$ \\
\hline 19 & Interpersonal Skill & Mengembangkan informasi & $0,2 \%$ \\
\hline
\end{tabular}

Sumber : Data diolah, 2021

Tabel 4 memperlihatkan bahwa di bidang yang berbeda dibutuhkan porsi keterampilan yang berbeda pula, tetapi dapat dilihat bahwa persentase antara setiap keterampilan tidak memiliki perbedaan yang begitu jauh. Keterampilan teknis (technical skill) memiliki peringkat pertama pada setiap bidang pekerjaan akuntansi.

Tabel 4. Peringkat Subgrup Keterampilan yang Dibutuhkan Oleh Lulusan Sarjana Akuntansi Pada Iklan Lowongan Kerja Online

\begin{tabular}{|clcccccc|}
\hline \multirow{2}{*}{ No } & \multirow{2}{*}{ Keterampilan } & \multicolumn{2}{c}{ Keuangan } & \multicolumn{2}{c|}{ Pajak } & \multicolumn{2}{c|}{ Audit } \\
\cline { 3 - 8 } & & Peringkat & $\%$ & Peringkat & $\%$ & Peringkat & $\%$ \\
\hline 1 & Technical Skill & 1 & $60,5 \%$ & 1 & $60,9 \%$ & 1 & $54,4 \%$ \\
2 & Intellectual Skill & 4 & $10,5 \%$ & 4 & $10,5 \%$ & 2 & $14,6 \%$ \\
3 & Personal Skill & 3 & $14,5 \%$ & 3 & $12,0 \%$ & 3 & $15,5 \%$ \\
4 & Interpersonal Skill & 2 & $15,0 \%$ & 2 & $17,0 \%$ & 3 & $14,5 \%$ \\
\hline
\end{tabular}

Sumber : Data diolah, 2021 
Hasil penelitian ini didukung oleh penelitian yang dilakukan [4] pemberi kerja mengharapkan pemahaman yang baik mengenai keterampilan dasar akuntansi. Dalam hal keterampilan teknis (Technical Skill) perusahaan memerlukan setidaknya pemahaman akuntansi yang baik tentang keterampilan dasar akuntansi [6]. Penelitian ini juga sejalan dengan penelitian yang dilakukan oleh [2] yang menyatakan bahwa technical skill lebih ditekankan dalam rekrutmen karyawan di Indonesia dibandingkan dengan Australia dan Selandia Baru. Seorang lulusan akuntansi tidak hanya membutuhkan keterampilan profesional akan tetapi penting bagi sarjana lulusan akuntansi untuk memiliki pengetahuan dan keterampilan teknis dasar akuntansi (Technical Skill). Keterampilan teknis (Technical Skill), seperti penggunaan teknologi informasi, sangat penting bagi akuntan pemula hingga akademisi harus mendukung pengembangan keterampilan tersebut. Penggunaan teknologi informasi merupakan salah satu keterampilan penting dalam memasuki dunia kerja karena pengusaha menginginkan akuntan yang mahir dalam menggunakan berbagai alat akuntansi, seperti Excel, MYOB, Xero, dan sistem database lainnya [12].

Lulusan akuntansi juga harus memiliki keterampilan interpersonal (interpersonal skill) diantaranya seorang lulusan sarjana akuntansi harus memiliki kemampuan komunikasi, presentasi, bekerja dalam tim, bahasa asing, mengembangkan informasi, dan jiwa kepemimpinan yang berguna untuk menyampaikan hasil kerja dengan penyampaian yang baik, dan untuk berkomunikasi dalam tim kerja, serta berguna untuk memimpin dalam tim kerja. Artinya, untuk memasuki pekerjaan di bidang akuntansi sarjana lulusan akuntansi harus memiliki dasar pengetahuan teknis dasar akuntansi yang kuat dalam bidang akuntansi. Pendidikan akuntansi disarankan untuk lebih mengembangkan keterampilan generik di perguruan tinggi seperti keterampilan komunikasi lisan [1]. Hasil penelitian ini didukung oleh penelitian yang dilakukan oleh [12] yang juga menemukan bahwa keterampilan interpersonal dan komunikasi merupakan keterampilan yang paling dibutuhkan oleh akuntan dalam menghadapi globalisasi. Juga didukung oleh penelitian yang dilakukan oleh [2] menemukan bahwa, Hasil analisis lowongan pekerjaan akuntansi menunjukkan bahwa keterampilan yang paling dibutuhkan oleh akuntansi untuk semua kategori audit, akuntansi keuangan, dan pajak adalah keterampilan interpersonal dan komunikasi.

Pengembangan kurikulum akuntansi pada bidang keuangan ditekankan kepada proses belajar mengajar keterampilan teknis dasar akuntansi (Technical Skill) dan keterampilan intelektual (Intellectual Skill). Diantara Keterampilan teknis dasar akuntansi, dan keterampilan intelektual, keterampilan personal, dan keterampilan interpersonal persentase yang dihasilkan tidak begitu berbeda jauh. Artinya, pada bidang keuangan lulusan sarjana akuntansi tidak hanya dituntut untuk memiliki kemampuan teknik seperti merancang laporan keuangan yang baik, menggunakan software akuntansi keuangan dan pengetahuan yang memadai tentang konsep dasar akuntansi keuangan, namun juga harus menguasai keterampilan intelektual meliputi cara bagaimana memecahkan masalah, mampu berpikir analitis, kreatif, dan kritis. Menguasai keterampilan personal (personal skill) yang berkaitan dengan karakter 
pribadi individu, meliputi tanggung jawab dalam melaksanakan pekerjaan, mampu bekerja di bawah tekanan dan deadline, berkepribadian yang baik, mampu beradaptasi dengan lingkungan sekitar, dan mampu memanajemen waktu dengan baik dan dapat bekerja lebih dari satu bidang (Multitasking). Seorang lulusan sarjana akuntansi yang ingin terjun dalam bidang keuangan harus mampu menguasai keterampilan Interpersonal, yaitu memiliki kemampuan berkomunikasi, artinya seorang lulusan sarjana akuntansi hendaknya memiliki bekal yang kuat untuk kemampuan berkomunikasi untuk berinteraksi dengan klien atau rekan bisnis yang memungkinkan untuk mereka meminta informasi terkait keuangan industri. Peran akuntan tidak hanya untuk menyusun laporan keuangan tetapi juga bagaimana mengkomunikasikan laporan keuangan tersebut kepada pihak yang berkepentingan [10].

Pendidik akuntansi dapat melibatkan spesialis komunikasi untuk mengidentifikasi keterampilan komunikasi yang paling penting dan secara efektif menyelesaikan berbagai kegiatan terkait akuntansi, serta berkolaborasi dengan spesialis komunikasi dalam merancang pengembangan kurikulum untuk menghasilkan keterampilan komunikasi yang diinginkan [8]. Seseorang yang bekerja di bidang keuangan tidak hanya memiliki perencanaan keuangan yang baik dan pengetahuan yang cukup tentang berbagai konsep keuangan tetapi juga harus mahir menjadi komunikator yang baik [2]. Maka dari itu secara keseluruhan lulusan sarjana akuntansi hendaknya memiliki keterampilan yang seimbang antara keterampilan teknis dasar akuntansi (Technical Skill) dan atribut dari keterampilan generik (Generic Skill).

Pengembangan kurikulum di bidang perpajakan juga dapat menekankan pada pengetahuan keterampilan teknis dasar akuntansi (Technical Skill) yaitu memiliki pengetahuan yang mendalam mengenai peraturan perpajakan Indonesia, terkait dengan software perpajakan yang disediakan oleh Direktorat Jenderal Pajak (DJP). Lulusan sarjana akuntansi juga diharapkan memiliki kemampuan interpersonal seperti kemampuan berkomunikasi yang baik, guna untuk menyampaikan pesan tidak hanya kepada pihak internal industri, melainkan pihak eksternal industri seperti pihak yang berkaitan dengan pembayaran pajak industri. Keterampilan komunikasi yang baik dapat mempermudah dalam memberikan informasi dan menangani masalah keterlambatan pembayaran pajak [2]. Terlihat juga bahwa antara keterampilan teknis dasar akuntansi (Technical skill) dan keterampilan generik (Generic Skill) tidak memiliki kesenjangan persentase yang begitu tinggi. Artinya seorang lulusan sarjana akuntansi dituntut untuk memiliki kemampuan yang seimbang antara keterampilan teknis dasar akuntansi (Technical Skill) dan atribut dari keterampilan generik (Generic Skill).

Pengembangan kurikulum pada bidang audit di perguruan tinggi, dapat menekankan pada keterampilan teknis dasar akuntansi (Technical Skill) sebagai dasar untuk terjun kedalam pekerjaan sebagai auditor. Tidak hanya keterampilan teknis dasar, penting bagi pendidik untuk memperhatikan atribut dari keterampilan generik (Generic Skill) yaitu interpersonal skill, personal skill, dan intellectual skill juga harus ditekankan karena dapat dilihat bahwa persentase antara tiga indikator tersebut tidak 
memiliki peradaban yang begitu jauh. Seperti seorang auditor dituntut mampu untuk berkomunikasi dengan kliennya yang memungkinkan bagi auditor untuk mengembangkan kemampuan komunikasinya pada setiap situasi di dunia kerja nantinya. Sejalan dengan [2] bahwa komunikasi penting bagi seorang auditor dalam bekerja. Keterampilan komunikasi yang baik juga perlu dimiliki oleh seorang auditor internal untuk dapat bersaing di pasar global. Auditor memanfaatkan keterampilan komunikasi di hampir setiap situasi yang mereka hadapi dalam memberikan informasi audit kepada klien untuk membuat keputusan bisnis yang tepat [9]. Keterampilan komunikasi merupakan faktor penting yang dapat mempengaruhi kinerja seorang auditor internal. Keterampilan komunikasi ini diperlukan oleh auditor internal untuk memperkuat efektivitas hasil audit internal [7] .

\section{Kesimpulan dan Saran}

Berdasarkan analisis lowongan kerja akuntansi yang dimuat pada situs lowongan kerja online mengenai keterampilan yang dibutuhkan oleh lulusan sarjana akuntansi di Indonesia, dapat disimpulkan bahwa permintaan industri yang terkait dengan tenaga kerja dibidang akuntansi yang paling banyak yaitu bidang keuangan disusul dengan bidang perpajakan, dan audit. Tetapi nyatanya, bidang audit banyak membutuhkan lulusan sarjana akuntansi, namun sangat jarang bagi kantor akuntan publik untuk mengiklankan lowongan kerja yang mereka butuhkan untuk bekerja sesuai bidang audit. Terlihat bahwa tidak semua industri menyebar informasi lowongan kerja yang dibutuhkannya di situs web lowongan kerja online. Terlihat juga bahwa keterampilan teknis dasar akuntansi (Technical skill) dan keterampilan interpersonal yaitu kemampuan komunikasi paling dibutuhkan oleh seorang lulusan sarjana akuntansi dalam memasuki dunia kerja yang ditawarkan oleh perusahaan di Indonesia. Keterampilan yang memiliki persentase hasil tertinggi antara lain keterampilan teknis (Technical skill), atribut keterampilan generik (Generic Skill) yaitu keterampilan interpersonal, keterampilan personal, dan keterampilan intelektual.

Dengan demikian proses pembelajaran pada perguruan tinggi di Indonesia harus lebih menekankan pada keterampilan keterampilan teknis dasar akuntansi (Technical Skill) dan keterampilan interpersonal yaitu kemampuan komunikasi sehingga lulusan sarjana akuntansi memiliki peluang yang lebih besar untuk memenuhi kualifikasi yang diharapkan dunia kerja.

Pada dasarnya, seorang lulusan sarjana akuntansi harus memiliki keterampilan yang seimbang antara keterampilan teknis dasar akuntansi, dan keterampilan generik (Intellectual skill, personal skill, dan interpersonal skill). Tetapi pada iklan lowongan pekerja online yang dituliskan secara eksplisit itu hanya terbatas pada indikator yang umum saja, tidak dijelaskan secara rinci dan mendalam mengenai atribut apa saja yang dibutuhkan untuk menunjang pekerjaan dibidang akuntansi. Akan tetapi iklan lowongan kerja online sumber data yang banyak digunakan karena informasi yang tersedia bisa diakses untuk umum. 
Hasil penelitian ini diharapkan dapat memberikan kontribusi bagi pengembangan kurikulum akuntansi dan pengetahuan bagi lulusan sarjana akuntansi mengenai keterampilan yang paling dibutuhkan oleh dunia kerja di Indonesia. Dengan mengetahui keterampilan yang paling dibutuhkan oleh dunia kerja, lulusan sarjana akuntansi diharapkan dapat mempersiapkan diri untuk memenuhi keterampilan yang dibutuhkan oleh dunia kerja agar lebih mudah diterima dalam industri yang diinginkan sesuai dengan bidang pekerjaan akuntansi.

Pada penelitian ini identifikasi kompetensi hanya melalui empat iklan lowongan kerja online merupakan keterbatasan dari penelitian ini. Periode penelitian yang relatif singkat juga membatasi penelitian ini untuk memperoleh informasi yang lebih luas dan komprehensif terkait dengan lowongan kerja. Dengan demikian, penelitian selanjutnya diharapkan dapat menggunakan sumber lowongan kerja yang lebih luas serta periode penelitian yang lebih panjang agar hasil penelitian lebih dapat di generalisir.

\section{Referensi}

[1] Bui, Binh Porter, B. (2010). The expectation-performance gap in accounting education: An exploratory study. Accounting Education, 19(1-2), 23-50. https://doi.org/10.1080/09639280902875556

[2] Ghani, M. A., \& Suryani, A. W. (2020). Professional Skills Requirements for Accountants: Analysis of Accounting Job Advertisements. Jurnal ASET (Akuntansi Riset), 12(2), 212-226.

[3] Heang, L. T., Mee, L. Y., Chithra, T., \& Ramalingam, L. (2019). Job Opportunities and Employability Skills Required of Business Graduates in Malaysia : An Investigation through Online Job Advertisements. Journal of Marketing Advances and Practices, 1(1), 37-49.

[4] Jackling, B., \& De Lange, P. (2009). Do accounting graduates' skills meet the expectations of employers? a matter of convergence or divergence. Accounting Education, 18(4-5), 369-385. https://doi.org/10.1080/09639280902719341

[5] Kurniawan, R. (2017). Keterampilan Dan Atribut Yang Dibutuhkan Oleh Lulusan Akuntansi Untuk Sukses Berkarir: Pengujian Senjangan Persepsi Mahasiswa Dan $\begin{array}{llll}\text { Pemberi Kerja. Tirtayasa Ekonomika, 12(1), } & 12 .\end{array}$ https://doi.org/10.35448/jte.v12i1.4434

[6] Low, M., Botes, V., Rue, D. Dela, \& Allen, J. (2016). Accounting Employers' Expectations -The Ideal Accounting Graduates. Journal of Business Education \& Scholarship of Teaching, 101010(11), 36-57.

[7] Narkchai, S., \& Fadzil, F. H. B. (2017). The communication skill on the performance of internal auditors in Thailand Public Limited Company. International Review of Management and Marketing, 7(4), 1-5.

[8] Siriwardane, H. P., Low, K. Y., \& Blietz, D. (2015). Making entry-level accountants better communicators: A Singapore-based study of communication tasks, skills, and attributes. Journal of Accounting Education, 33(4), 332-347. https://doi.org/10.1016/j.jaccedu.2015.08.001 


\section{AKUTNIANSI}

[9] Smith, G. (2005). Communication skills are critical for internal auditors. Managerial Auditing Journal, 20(5), 513-519. https://doi.org/10.1108/02686900510598858

[10] Srirejeki, K. (2015). Kemampuan Komunikasi Mahasiswa Akuntansi: Tinjauan Literatur. Jp.Feb.Unsoed, Vol 5, No.

[11] Sugiyono. (2012). Metode Penelitian Kuantitatif, Kualitatif, dan Tindakan.

[12] Tan, L. M., \& Laswad, F. (2018). Professional skills required of accountants: what do job advertisements tell us? Accounting Education, 27(4), 403-432. https://doi.org/10.1080/09639284.2018.1490189 